\title{
トドマツ精英樹等クローンにおける容積密度の樹高方向での 变動とピロディンを用いた非破壊的評価*1
}

\author{
井城泰一 $* 2$, 田村 明 $* 2$, 西岡直樹 $* 2$, 阿部正信 $* 2$, 飯塚和也 $* 3$
}

\section{Longitudinal Changes of Basic Density and Non-Destructive Quality Evaluation Using the Pilodyn in Todomatsu (Abies sachalinensis) Plus Tree Clones*1}

\author{
Taiichi IkI*2, Akira TAMURA*2, Naoki NiSHIOKA*2, \\ Masanobu ABE*2 and Kazuya IIzUKA*3
}

\begin{abstract}
The longitudinal changes in the basic density of disks (mean Bd) of todomatsu (Abies sachalinensis) were investigated using plus-tree clones and breeding-material clones. The relationship between Pilodyn penetration of a standing tree and mean $B \mathrm{~d}$ was also investigated. The patterns of longitudinal change of mean $B \mathrm{~d}$ differed among clones and could be classified into several types. The mean $B \mathrm{~d}$ of the region 1-3 $\mathrm{m}$ above ground could be used as an alternate value to the mean $B \mathrm{~d}$, and including breast height was appropriate for a genetic comparison. A significant negative correlation between Pilodyn penetration of a standing tree with and without bark and mean $B d$ was obtained in both individuals and clones. Pilodyn penetration with bark was more useful than that without bark because it was easier. Therefore, it would be possible to evaluate the mean $B \mathrm{~d}$ in todomatsu based on the measurement of Pilodyn penetration with bark of standing trees at breast height. This method will allow us the non-destructive evaluation, and will be available as a good indicator of the wood quality of both individuals and clones.
\end{abstract}

Keywords: $\quad$ todomatsu, clone, longitudinal change, basic density, Pilodyn penetration.

トドマツ精英樹や育種母材のクローンを用いて, 円板全体の容積密度（平均容積密度）の樹高 方向の変動を調査した。また，立木状態で測定したピロディンによる打ち込み深さ（ピロディン 值）と平均容積密度との関係を調査した。平均容積密度の樹高方向の変動パターンはクローンご とに異なっており，いくつかのタイプに分類できた。平均容積密度の最適な測定部位を検討した 結果, 地際からの高さ 1 3 $\mathrm{m}$ 部位において樹幹を代表する值として用いることが可能であり, この地上高部位において遺伝的な違いを比較できると考えられた。立木状態で樹皮の上から測定 したピロディン值（樹皮付きピロディン值），樹皮を剥皮したピロディン值（ピロディン值）と 平均容積密度の間には，個体值，クローン平均值とも有意な負の相関関係が認められた。測定の 簡便さから，樹皮付きピロディン值が有効な指標であると考えられた。以上より，胸高部位で卜 ドマツの立木の樹皮付きピロディン值を測定することで，非破壊的に個体やクローンの平均容積 密度を評価する有効な材質指標になることが示唆された。

\footnotetext{
*1 Received May 14, 2007 ; accepted June 6, 2008. 本研究の一部は第56回日本木材学会大会（2006年 8 月，秋田）におい て発表した。

*2 森林総合研究所林木育種センター北海道育種場 Forest Tree Breeding Center Hokkaido Regional Breeding Office, Forestry and Forest Products Research Institute, Ebetsu 069-0836, Japan

*3 宇都宮大学農学部 Faculty of Agriculture, Utsunomiya University, Utsunomiya 321-8505, Japan
} 


\section{1. 緒言}

トドマッ (Abies sachalinensis Masters) は，北海 道の郷土樹種であり，主要な造林樹種の一つである。 その用途は多様であるが，主に構造材などの建築用 材に多く使用されている。

木材は将来的に工業用原材料としての利用が予想 されており ${ }^{1)}$, 客観的な指標として, 材質が重要に なっていくと考えられる。重要な材質指標の一つに 容積密度がある。容積密度は, 圧縮やせん断強さな どの木材の力学的性能や木材収量の指標として重要 な材質形質である。また近年, 地球温暖化の原因の 一つと言われている二酸化炭素を固定する能力を評 価する指標としても重要視されている。しかし，ト ドマツ造林木の欠点として, 容積密度の低い材がし ばしば現れることが指摘されている の低い材が現れることは, 構造材などの建築用材と してのトドマツ材の経済的価值を低くする原因の一 つであり，木材利用や二酸化炭素の固定能力を考元 ると容積密度の高いトドマツが望まれる。トドマツ の容積密度は, クローン間 ${ }^{5-9)}$ や家系間 ${ }^{10)}$ で有意な 差のあることが報告されている。また，親子回帰か ら推定した狭義の遺伝率も比較的高いことから ${ }^{10)}$, トドマツの容積密度は遺伝的要因の寄与が高い形質 であると考えられ，遺伝的改良によりその向上が期 待できる。トドマッの人工造林は種子による実生苗 が植栽されるため，材質形質の遺伝的改良を行うた めには, 設定済みの採種園を優れた形質のクローン 構成へ, 改良あるいは誘導することが重要となる。

容積密度の遺伝的改良を目指し，個体㧍よびク口 ーンの選抜を行うためには, 樹幹内の変動を把握し, 有効で効率の上い調查を行うための地上高部位を検 討する必要がある。樹高方向の容積密度の変動は, スギ ${ }^{11-14)}$ やヒノキ13,15)，カラマッ13,16) で行われてい る。またスギでは, 胸高部位の平均密度と樹幹全体 の平均密度との間に強い正の相関関係があり, 胸高 部位の測定值で樹幹全体を代表できることが報告さ

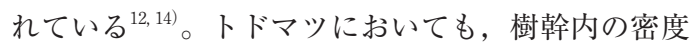
分布を三次元的に図示した報告 ${ }^{17)}$ や，胸高部の平 均密度と樹幹全体の平均密度を比較した報告 ${ }^{13)}$ は ある。しかし，その供試本数はあまり多くなく，ま た遺伝的に由来の明らかな育種素材を供試し, 容積 密度の樹高方向変動を検討した報告は見られない。

これまでトドマツの容積密度の測定は，間伐材な どの伐倒木を対象に行われてきた。しかし，伐倒木 による調查は, 多くの時間や労力, 経費を要する。 また，検定林や採種園では，その本来の目的の維持
のため, 材質評価を行う調査木の採取できるサンプ ル数やその選抜に制限がある。そこで立木状態で簡 易的に容積密度を推定できる手法として，ピロディ ンやレジストグラフを用いた方法が検討されてい る。ピロディン（スイス連邦，PROCEQ 社製）は， 電柱の腐朽度の検査用として開発されたもので, 6 ジュールのカでストライカーピンを木材に打ち込 み，その打ち达み深さを計測する機器である。これ まで, ピロディンの打ち込み梁さ（以下，「ピロデ イン值」とする。）と容積密度との関係を報告した 例は多い吕-23)。日本に执いても，スギ20,21)，ヒノ キ22) やカラマッ ${ }^{23)}$ においてピロデイン值と容積密 度との関係を調べ，立木状態で非破壊的な方法とし て，その有用性が報告されている。しかし，トドマ ツを対象にピロディン值と容積密度との関係を検討 した報告はない。

そこで本研究では, 北海道江別市にある独立行政 法人森林総合研究所林木育種センター北海道育種場 （以下，「北海道育種場」とする。）内のトドマッ交 配園に植栽されていたトドマツ精英樹と育種母材 （以下，「トドマツ精英樹等」とする。）を用いて， トドマツに扔ける樹幹全体の容積密度を評価する最 適部位の検討を行うために，容積密度の樹高方向の 変動を調べた。また, 北海道育種場内の育種素材保 存園に植栽されていたトドマツ精英樹等クローンを 用いて, ピロディンによる容積密度の非破壊的評価 法の有効性を検討するため, 立木状態でピロディン 值を, 伐倒後に採取した円板より容積密度を測定し, その関係を調査した。

\section{2. 材料と方法}

\section{1 トドマツ精英樹等クローンにおける容積密度 の樹高方向の変動}

樹高方向の容積密度の測定には，北海道育種場内 にあるトドマツ交配園から供試木を得た。同交配園 は1962年春, 平坦地に単木混交植栽で設定された。 2004年 8 月に供試木を伐倒し， 7 クローン18本の材 料を得た。伐倒時の林齢は 43 年生であった。供試木 の概要を Table 1 に示す。伐倒後, 材長 $1 \mathrm{~m}$ の丸太 を地際から順に採取し, 最大で13番玉まで丸太を得 た。採取した丸太から端の部分を除いた節などの欠 点のない部分より, 厚さ約 $10 \mathrm{~cm}$ の円板を採取した。 円板より髄を含むストリップを切り出し, ビニール 袋で密閉し測定まで- $15{ }^{\circ} \mathrm{C}$ の冷凍庫で保存した。な お，腐朽や節，あてなどの欠点を除いた計 170 個の ストリップを容積密度の測定に供した。容積密度の 測定前に, 䯣から 2 方向の年輪幅を測定した。容積 
Table 1. Descriptions of sample trees from a seed orchard.

\begin{tabular}{|c|c|c|c|c|c|c|}
\hline Clone name & kind of clone & $\begin{array}{l}\text { Tree } \\
\text { No. }\end{array}$ & $\begin{array}{l}\mathrm{h}^{(\mathrm{b})} \\
(\mathrm{m})\end{array}$ & $\begin{array}{c}\mathrm{DBH}^{(c)} \\
(\mathrm{cm})\end{array}$ & $\begin{array}{l}\text { Number } \\
\text { of log }\end{array}$ & $\begin{array}{l}\text { Number } \\
\text { of disk }\end{array}$ \\
\hline \multirow{3}{*}{ Esashi101 } & \multirow{3}{*}{ Plus tree } & 1 & 14.7 & 33.0 & 13 & 9 \\
\hline & & 2 & 14.2 & 36.0 & 13 & 11 \\
\hline & & 3 & 15.2 & 30.0 & 13 & 10 \\
\hline \multirow{2}{*}{ Gamushi103 } & \multirow{2}{*}{ Plus tree } & 1 & 14.2 & 20.0 & 11 & 8 \\
\hline & & 2 & 12.9 & 28.0 & 10 & 5 \\
\hline \multirow{3}{*}{ Nayoro103 } & \multirow{3}{*}{ Plus tree } & 1 & 15.3 & 27.0 & 13 & 13 \\
\hline & & 2 & 13.1 & 27.0 & 10 & 10 \\
\hline & & 3 & 15.1 & 24.0 & 13 & 11 \\
\hline \multirow{2}{*}{ Rikubetsu102 } & \multirow{2}{*}{ Plus tree } & 1 & 14.4 & 33.0 & 12 & 8 \\
\hline & & 2 & 13.0 & 30.0 & 11 & 10 \\
\hline \multirow{3}{*}{ Shimokawa125 } & \multirow{3}{*}{ Plus tree } & 1 & 14.3 & 27.0 & 11 & 8 \\
\hline & & 2 & 14.7 & 24.0 & 11 & 9 \\
\hline & & 3 & 14.4 & 26.0 & 12 & 10 \\
\hline \multirow{2}{*}{ Akan101hi1 } & \multirow{2}{*}{ Breeding material $^{(\mathrm{a})}$} & 1 & 11.5 & 17.0 & 8 & 6 \\
\hline & & 2 & 11.5 & 18.0 & 8 & 6 \\
\hline \multirow{3}{*}{ Hiroshima102 } & \multirow{3}{*}{ Breeding material } & 1 & 13.4 & 20.0 & 11 & 11 \\
\hline & & 2 & 15.8 & 24.0 & 13 & 13 \\
\hline & & 3 & 15.1 & 19.0 & 12 & 12 \\
\hline
\end{tabular}

Legend : ${ }^{(a)}$ : grafting clone but not plus tree, ${ }^{(b)}$ : tree height, ${ }^{(c)}$ : diameter at $1.3 \mathrm{~m}$ above ground.

密度の測定に用いた試験体は髄から 5 年輪ごとにノ ミを用いて作成した。容積密度は数式 $B \mathrm{~d}=W_{\mathrm{o}} / \mathrm{V}_{\mathrm{g}} \times$ 1000 により算出した。ここで $B \mathrm{~d}$ は容積密度 $\left(\mathrm{kg} / \mathrm{m}^{3}\right)$, $W_{\mathrm{o}}$ は全乾重量 $(\mathrm{g}) ， V_{\mathrm{g}}$ は生材体積 $\left(\mathrm{cm}^{3}\right)$ である。 生材体積は浮力法の定法に従って測定した。21年輪 以降の容積密度は，まとめて一つの試験体として測 定した。また円板全体の容積密度を評価するため, 各試験体の面積を加重した容積密度（以下，「平均 容積密度」とする。）を数式 Mean $B \mathrm{~d}=\Sigma B \mathrm{~d}_{n} \times A_{n} / \Sigma$ $A_{n}$ より算出した。ここで Mean $B \mathrm{~d}$ は平均容積密度 $\left(\mathrm{kg} / \mathrm{m}^{3}\right), B \mathrm{~d}_{n}$ は $n$ 番目の試験体の容積密度, $A_{n}$ は $n$ 番目の試験体の面積 $\left(\mathrm{cm}^{2}\right)$ である。各試験体の 面積は，䯣からの距離を半径とする同心円を仮定し て算出した。なお， 1 番丸太を地上高 $1 \mathrm{~m}$ 部位（地 際から $1 \mathrm{~m}$ までの部位)，2 番丸太を地上高 $2 \mathrm{~m}$ 部 位（地際からの高さ $1 \mathrm{~m}$ から $2 \mathrm{~m}$ までの部位）と, 各丸太を各地上高部位とし，それぞれの丸太から採 取した円板より得た測定値を各地上高部位の測定値 として解析に用いた。

\section{2 立木状態のピロディン值と容積密度との関係}

供試木は，北海道育種場内のトドマッ育種素材保 存園より得た。同保存園は，1961年春と秋に，平坦 地にクローンごとの列状植栽で設定された。伐倒時 の林齢は44年生であった。伐倒前の2004年 8 月に, ピロディン值を測定した。測定は胸高部位付近にお いて 4 方向で行い，その平均值を個体值とした。測
定は最初に樹皮の上から行い, その後, 最初の測定 付近の樹皮を剥皮し行った。供試木は2004年 8 月〜 9 月にかけて伐倒した。伐倒木の胸高部位付近より 厚さ約 $10 \mathrm{~cm}$ の円板を採取し2.1節と同様な方法で年 輪幅と容積密度を測定し, 平均容積密度を算出した。 円板から切り出したストリップより 2 方向の樹皮の 厚さをデジタルノギスで測定し，その平均值を樹皮 厚とした。樹皮が剥がれてしまい 1 方向しか測定で きなかった個体は，その測定值を用いた。なお，あ てなどの欠点があった個体を除いた44クローン135 個体（各クローンあたり $1 \sim 8$ 個体）を容積密度の 測定に供した。また，樹皮がすでに剥がれてしまっ ていた個体が10個体（すべて別クローン）あり，樹 皮厚の解析に用いた個体は43クローン125個体であ った。

\section{3 統計解析}

本研究で行った分散分析および回帰分析は, 農林 水産研究計算・情報センターの科学技術計算システ ムの統計解析ソフト SAS を用いて行った。

\section{3. 結果と考察}

\section{1 樹高方向におけるトドマツ精英樹等クローン の平均容積密度の変動}

3.1.1 樹高方向の平均容積密度の変動

各個体の平均容積密度の樹高方向の変動を Fig. 1 に示す。同一クローン内における各個体の平均容積 

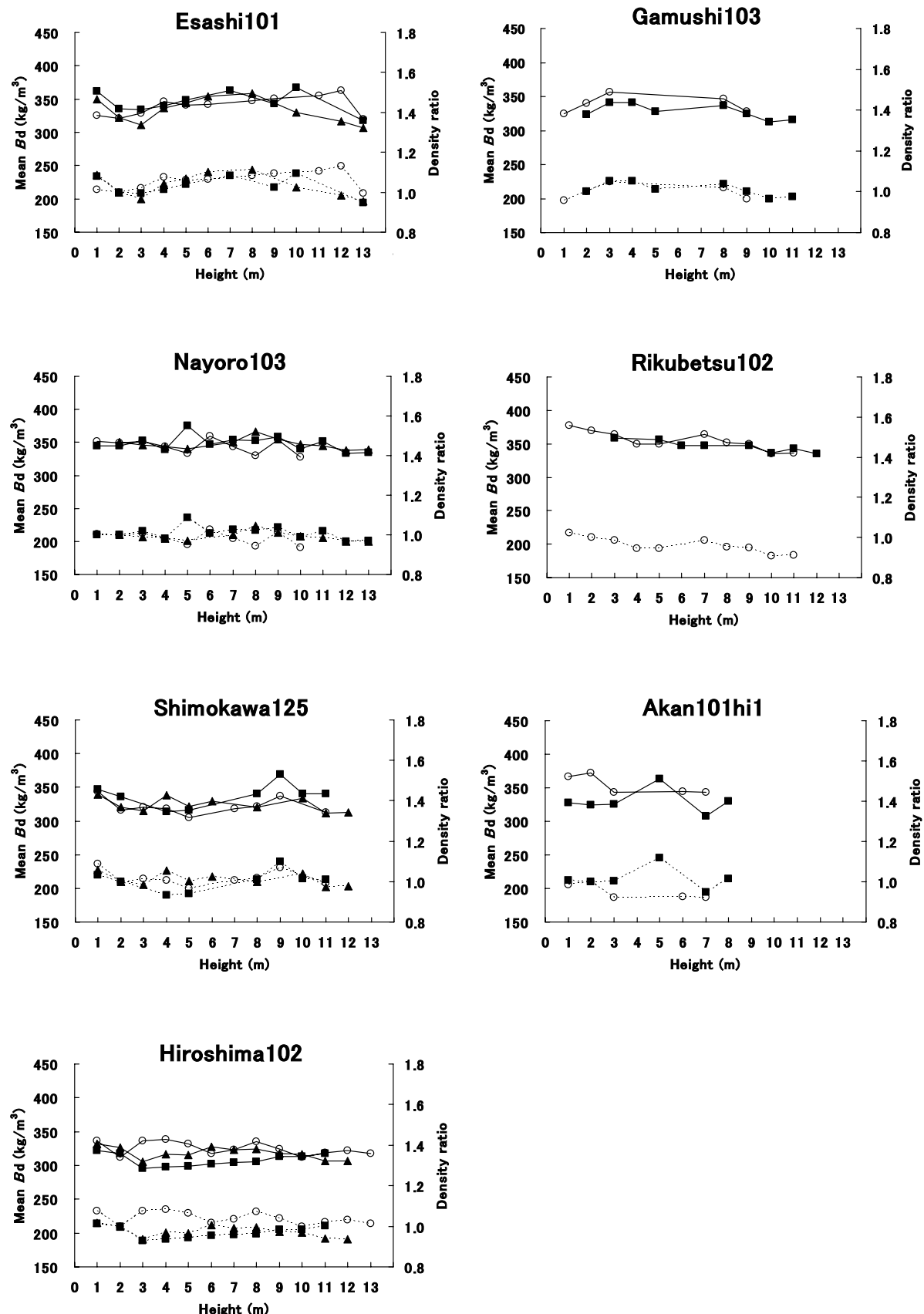

Fig. 1. Longitudinal changes of mean $B d$ and density ratio for individuals

Legend: $\mathbf{\square}$ : tree No. $1, \bigcirc$ : tree No. 2, $\boldsymbol{\Delta}$ : tree No. 3, Bd : basic density.

Note: Solid lines show the longitudinal changes of mean $B d$. Broken lines show the longitudinal changes of density ratio.

密度の変動パターンは，おおむね同様の傾向を示し た。しかし，その変動パターンはクローンにより異 なっていた。本研究で用いた供試材料では, 地際に
近い部分から地上高が高くなるにつれて減少する が，地上高 4 8 m 部位付近に扔いて増加し，梢頂 付近で再び減少するタイプ（枝幸101号, 陸別102号, 
下川125号, 広島102号), 地際からほほ一定で推移 し梢頂付近で減少するタイプ (名寄103号), 地上高 が高くなるにつれて増加し梢頂付近において減少す るタイプ（俄虫103号，阿寒101比 1 号）に分類でき ると考えられる。トドマツ精英樹クローンの容積密 度の評価は，これまで胸高部位付近より円板を採取 し行われてきた ${ }^{5-9)}$ 。そこで, 胸高部位を含む地上 高 $2 \mathrm{~m}$ 部位の平均容積密度を 1 として他の地上高部 位の平均容積密度を相対值に変換し(この值を以下, 「密度比」とする。， その樹高方向の変動も Fig. 1 に示す。なお，陸別102号の No.2（㽞）の個体は, 地上高 $2 \mathrm{~m}$ 部位の平均容積密度を測定できなかった ため図示していない。密度比の変動パターンも平均 容積密度と同様に，同一クローン内の各個体はほぼ 同様の傾向を示したが，クローン間で異なっている と考えられる。しかし，ほとんどの地上高部位にお いて密度比が0.9 1.1の間にあり，トドマツにおけ る同様の報告 ${ }^{13)}$ に比べやや大きな值を示したが, 胸高部位を含む地上高 $2 \mathrm{~m}$ 部位と他の地上高部位と の平均容積密度の差は小さいと考えられる。

つぎに，分割した各年輪部位の容積密度と年輪幅 の樹高方向の変動を Fig. 2 および Fig. 3 に示す。Fig. 2 に名寄103号の 3 個体を, Fig. 3 に広島102号の 3 個 体を示す。名寄103号と広島102号は，供試した個体 数が多く, Fig. 1 に示した平均容積密度の樹高方向 の変動パターンが異なると考えられたクローンであ る。各年輪部位の容積密度の樹高方向の変動におい て, これら 2 クローン間の共通した特徴として, 各 地上高部位において $1 \sim 5$ 年輪部位で低い容積密度 を示し，11～15年輪部位あるいは16～20年輪部位で 高い容積密度を示す傾向にあった。また， 6 ～10年 輪部位あるいは21年輪以降の年輪部位の容積密度 は, その中間の值を示す傾向にあった。この傾向は, 他の 5 クローンの各個体においても共通していた。 このように各年輪部位の容積密度の順位の変動は, 地上高間に扔いて小さいと考えられる。また，分割 した各年輪部位における年輪幅の樹高方向の変動 は, 名寄103号で11〜 15年輪部位および16〜20年輪 部位が，広島102号で 6 〜 10年輪部位および11〜15 年輪部位がそれぞれ広い年輪幅を示す傾向にあっ た。また両クローンとも，21年輪以降の年輪部位に おいて狭い年輪幅を示す傾向にあった。

Fig. 2 および Fig. 3 より, 各年輪部位の容積密度 の順位の変動は地上高間に扔いて小さいと考えられ たが, 各年輪部位の容積密度の樹高方向の変動パ夕 ーンは, Fig. 1 で示した平均容積密度の変動パター ンと比べ，年輪部位によって異なる傾向を示した。
そこで, 各年輪部位の容積密度が平均容積密度に対 してあたえる影響を明らかにするため，地上高部位 毎に各年輪部位の容積密度と平均容積密度との相関 係数を求め, その変動を Fig. 4 に示す。各地上高部 位に打いて辺縁に近い年輪部分で高い相関係数を示 す傾向にあった。特に各地上高部位において 21 年輪 以降の部位は相関係数が高く, 平均容積密度に対す る影響が大きいと推察された。また, Fig. 3 で示し た広島102号の No. 3 に扔ける地上高 $1 \mathrm{~m}$ および $2 \mathrm{~m}$ 部位では, 他の地上高部位とは異なり, $1 \sim 5$ 年輪 部位の容積密度が高かった。その原因として,この 部位の年輪幅が他の地上高部位と比べ狭かったこと が考えられる。このように，個々の年輪部位におい て年輪幅の大きさが容積密度に影響を与えている可 能性が考えられた。そこで各年輪部位の容積密度に 対する年輪幅の影響を明らかにするため, 地上高部 位毎に各年輪部位の容積密度と年輪幅の相関係数を 求めた。その結果，相関係数を求めた全 44 個の年輪 部位中35個の年輪部位において統計的に有意な相関 関係が認められなかった。また, 有意な関係が認め られた 9 個の年輪部位（2 個が $1 \%$ 水準， 7 個が 5 \%水準であった。)に抏いても相関係数は低かった。 このため, 個々の年輪部位において容積密度に対す る年輪幅の影響があると考えられたが，ほとんどの 相関係数が低かったことからトドマツの樹幹全体に おける容積密度に対する年輪幅の影響は小さいと考 えられる。

3.1.2 樹幹全体の平均容積密度を示す地上高部位 の検討

前節の結果から, 平均容積密度の樹高方向の変動 パターンはクローン間で異なると考えられた。そこ で, 平均容積密度に対するクローンと地上高の影響 を調べるため, 以下の式(1)に示した線型モデルを 仮定して分散分析を行った。

$$
\mathrm{y}_{i j k}=\mu+\mathrm{C}_{k}+\mathrm{H}_{j}+(\mathrm{CH})_{j k}+\varepsilon_{i j k}
$$

ここで $\mathrm{y}_{i j k}$ はクローン $k$ の個体 $i$ における地上高 $j$ の測定值, $\mu$ は全平均, $\mathrm{C}_{k}$ はクローン $k$ の効果, $\mathrm{H}_{j}$ は地上高 $j$ の効果, $(\mathrm{CH})_{j k}$ はクローン $k$ に抢ける地 上高 $j$ の効果， $\varepsilon_{i j k}$ は䛊差である。その結果を Table 2 に示す。クローン間に抒いて $1 \%$ 水準で，地上高 間に抒いて $5 \%$ 水準で有意差が認められた。クロー ンと地上高の交互作用に扔いて有意差は認められな かった。分散分析の結果から, トドマツ精英樹等ク ローンに扔ける平均容積密度は, クローン間, 地上 高間で異なり, 各地上高部位におけるクローン間差 およびその順位の変動が小さいと考えられる。トド マッでは円板を採取する地上高部位を統一すること 


\section{Nayoro103}

\section{Tree No. 1}
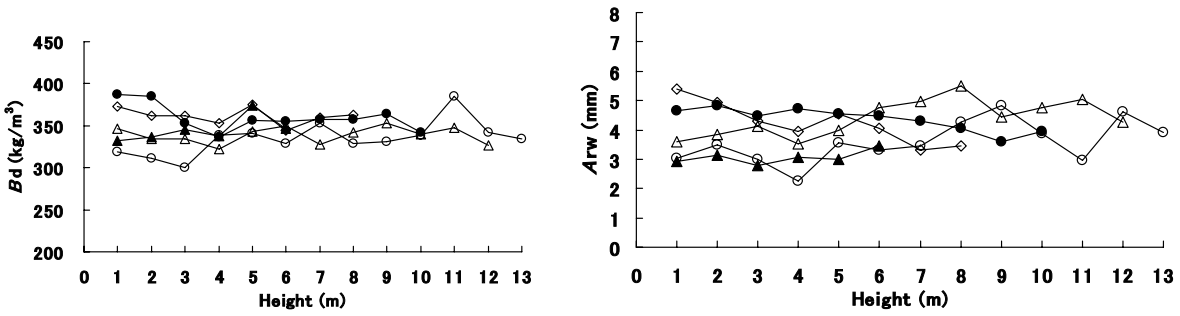

\section{Tree No. 2}
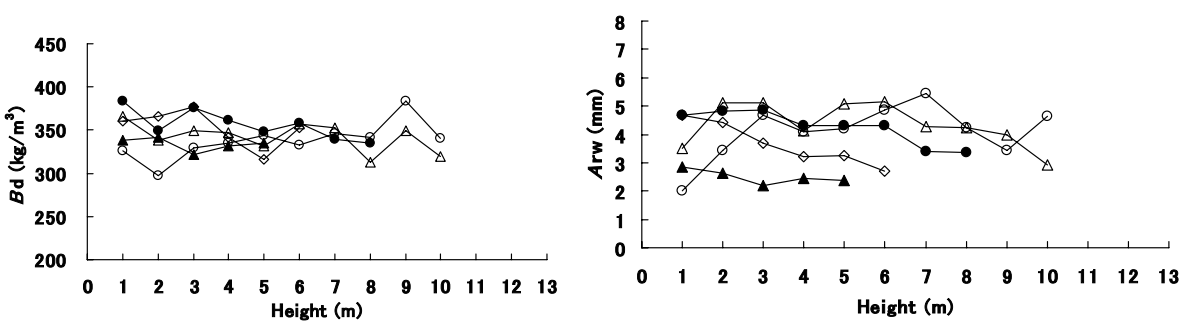

\section{Tree No. 3}
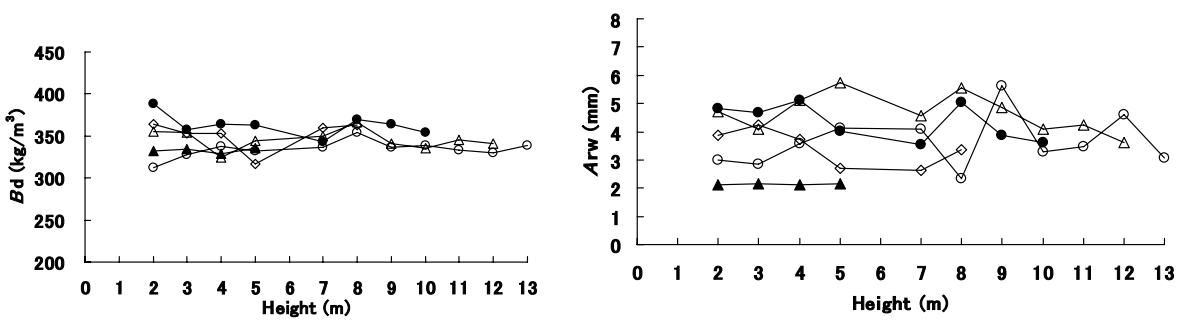

Fig. 2. Longitudinal changes of $B \mathrm{~d}$ and $A$ rw of each specimen split into strips of 5 annual rings each in Nayoro 103.

Legend: $\bigcirc$ : specimen of 1-5 annual ring numbers from the pith, $\triangle$ : specimen of 6-10 annual ring numbers from the pith, 0 : specimen of 11-15 annual ring numbers from the pith, $\diamond$ : specimen of 16-20 annual ring numbers from the pith, $\boldsymbol{\Delta}$ : specimen of 21 -annual ring numbers from the pith, $B$ d : basic density, $A$ rw : annual ring width.

により，平均容積密度の遺伝的違いを評価できると 考えられる。また， $F$ 值は地上高に比べてクローン の方が大きかった。クローン間の平均容積密度の差 が地上高間の差に比べて大きいと考えられる。スギ 精英樹クローンにおける同様の報告 ${ }^{14)}$ では, 地上 高間において $0.1 \%$ 水準で有意な差が認められてい る。この結果から，トドマツはスギに比べ樹高方向 の平均容積密度の変動が小さいと考えられる。

Fig. 2 および Fig. 3 より, 各年輪部位の容積密度
の樹高方向の変動パターンは, Fig. 1 で示した平均 容積密度の変動パターンと比べ, 年輪部位によって 異なる傾向を示した。そこで，各年輪部位の容積密 度に対する地上高とクローンの影響を調べるため, 式 (1) で示した線型モデルを仮定し分散分析を行っ た。その結果を Table 3 に示す。すべての年輪部位 においてクローン間に $1 \%$ 水準で有意差が認められ た。また地上高間では，21年輪以降の部位において 有意差が認められなかったが，その他の各年輪部位 


\section{Hiroshima102}

\section{Tree No. 1}
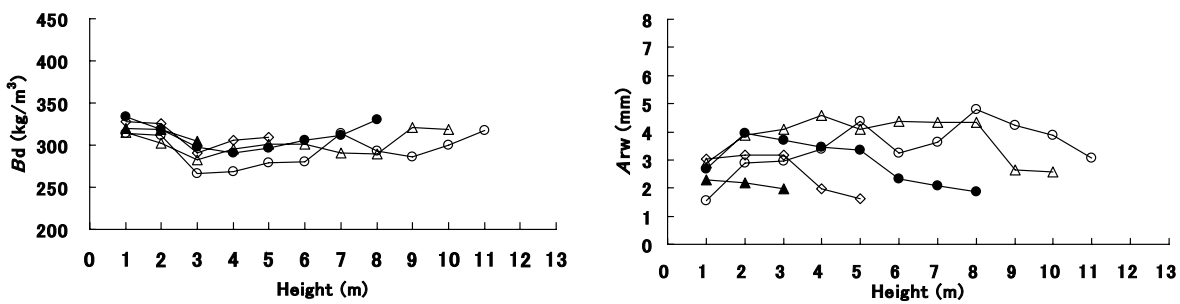

Tree No. 2
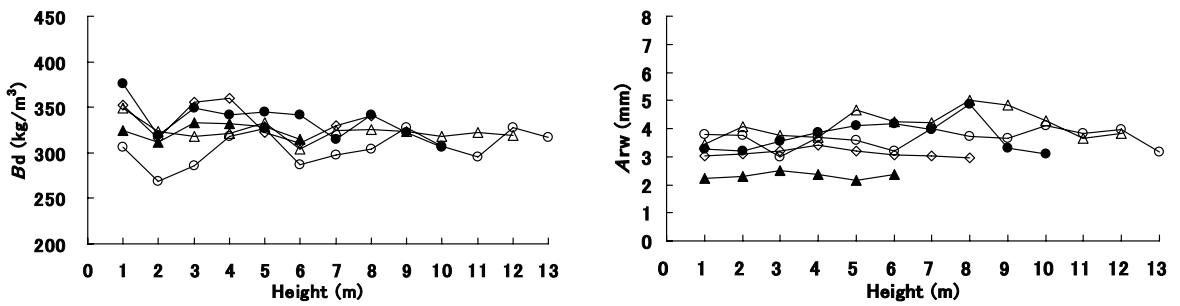

\section{Tree No. 3}
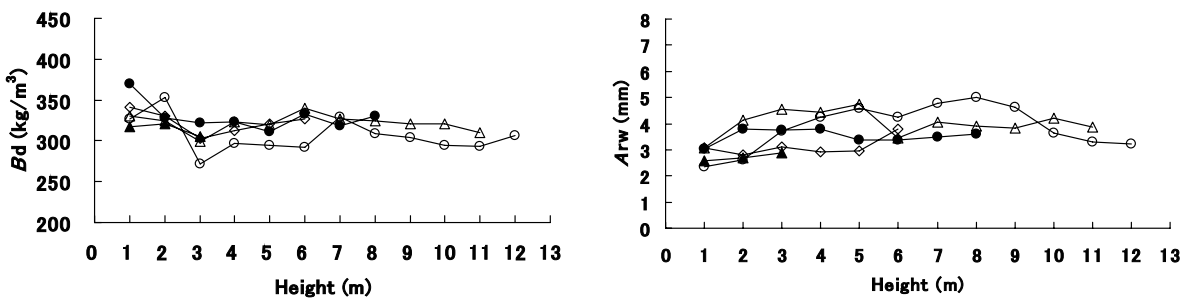

Fig. 3. Longitudinal changes of $B \mathrm{~d}$ and $A$ rw of each specimen split into strips of 5 annual rings each in Hiroshima 103.

Legend: See Fig. 2.

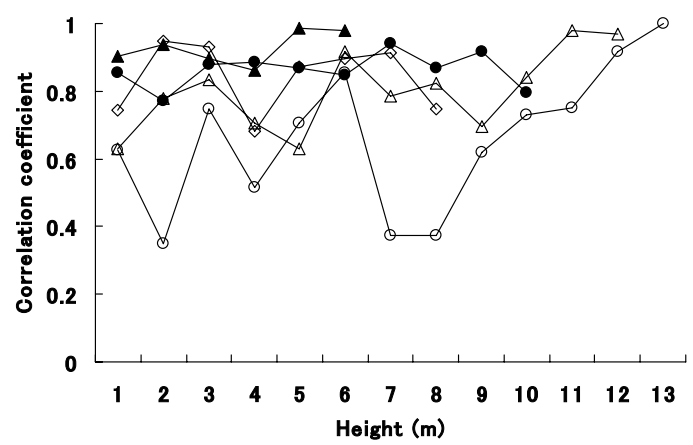

Fig. 4. Longitudinal changes of correlation coefficient between mean $B \mathrm{~d}$ and $B \mathrm{~d}$ of each specimen.

Legend: $\bigcirc, \triangle, \boldsymbol{O}, \diamond, \boldsymbol{\Delta}$ : See Fig. $2, B d$ : basic density.
Table 2. The result from ANOVA of mean Bd for both clone and height.

\begin{tabular}{crrrr}
\hline \hline Factor & $\mathrm{df}^{(\mathrm{a})}$ & \multicolumn{1}{c}{$\mathrm{SS}^{(\mathrm{b})}$} & \multicolumn{1}{c}{$\mathrm{MS}^{(\mathrm{c})}$} & $F^{\text {-value }}$ \\
\hline Clone & 6 & 23971.23 & 3995.20 & $20.76^{* *}$ \\
Height & 12 & 4980.33 & 415.03 & $2.16^{* *}$ \\
Clone $\times$ Height & 63 & 15103.99 & 239.75 & 1.25 n.s. \\
Eroor & 97 & 18667.67 & 192.45 & \\
\hline Legend : ${ }^{(a)}$ : degrees of freedom, ${ }^{(b)}:$ sum of squares, ${ }^{(c)}$ : \\
mean square, ${ }^{* *}$ : significant at 1\% level, ${ }^{*}$ : \\
significant at 5\% level, n.s. : not significant, Bd : \\
basic density.
\end{tabular}

において $1 \%$ 水準で有意差が認められた。クローン と地上高の交互作用は，すべての年輪部位で有意差 は認められなかった。各年輪部位の容積密度におけ 
Table 3. The result from ANOVA of each specimen for both clone and height.

\begin{tabular}{cclc}
\hline \hline \multirow{2}{*}{$\begin{array}{c}\text { specimen } \\
\text { Annual ring numbers } \\
\text { from the pith) }\end{array}$} & \multicolumn{3}{c}{ Factor } \\
\cline { 2 - 4 } & Clone & Height & Clone $\times$ Height \\
\hline $1-5$ & $15.52^{* *}$ & $2.68^{* *}$ & 0.93 n.s. \\
$6-10$ & $12.40^{* *}$ & $3.33^{* *}$ & 0.85 n.s. \\
$11^{-15}$ & $11.83^{* *}$ & $3.20^{* *}$ & 0.94 n.s. \\
$16^{-} 20$ & $6.57^{* *}$ & $3.12^{* *}$ & 0.84 n.s. \\
$21^{-}$ & $11.28^{* *}$ & 1.29 n.s. & 0.87 n.s. \\
\hline
\end{tabular}

Legend: ${ }^{(a)}$ : specimen which split a strip into 5 annual ring numbers from the pith, ${ }^{* *}$ : significant at $1 \%$ level, n.s. : not significant.

る分散分析の結果は，平均容積密度の結果とほほ同 様の結果であった。また $F$ 值の大きさから，平均 容積密度と同様に各年輪部位の容積密度において も，地上高間の差よりクローン間の差の方が大きい と考えられる。

個体間，クローン間の平均容積密度の比較を行う には，樹幹全体の平均容積密度を代表する地上高部 位を明らかにする必要がある。樹幹全体の平均值と 各地上高測定值との相関係数を求め, 最も相関係数 の高い地上高部位がその個体の樹幹全体の平均容積 密度を精度よく推定できる最適部位であると考えら れる。そこで各個体の樹幹全体の平均容積密度の平 均值と各地上高部位の平均容積密度の相関係数を求 め，その結果を Fig. 5 に示す。地上高 1 $11 \mathrm{~m}$ 部位 に扔いて $1 \%$ 水準で, $12 \mathrm{~m}$ 部位に扔いて $5 \%$ 水準 で有意な正の相関関係が認められた。地上高 $13 \mathrm{~m}$ 部位では有意な相関関係は認められなかった。最も 相関係数が高かった地上高部位は $7 \mathrm{~m}$ 部位であった が，地上高 $2 \mathrm{~m}$ 部位および $3 \mathrm{~m}$ 部位における相関係 数はそれぞれ0.836，0.832と高い值を示し， 2 番

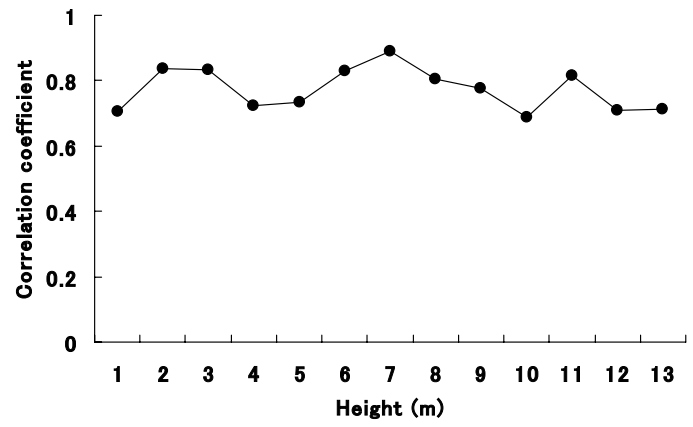

Fig. 5. Longitudinal changes of correlation coefficient between mean $B \mathrm{~d}$ at each height and its mean in the whole tree.

Legend: $B \mathrm{~d}$ : basic density.
目， 3 番目に高かった。これらの結果より，トドマ ッでは，胸高部位を含む地際からの高さ $1 \sim 3 \mathrm{~m}$ の 部位においてクローンや個体の平均容積密度の比較 を行う最適な部位であると考えられる。

またトドマッの容積密度は，これまで胸高部位付 近における測定結果が多く報告されている こで，樹幹全体の容積密度を推定するのに最適な年 輪部位を明らかにするため, 樹幹全体の平均値と地 上高 $2 \mathrm{~m}$ 部位に扔ける各年輪部位の容積密度との関 係を Fig. 6 に示す。辺縁部の年輪部位ほど高い相関 係数を示し，21年輪以降の部位との相関係数は 0.814 ( $1 \%$ 水準で有意) と高い值を示した。この結果から， 胸高部位の辺縁に近い21年輪以降の部位の容積密度 を測定することにより，樹幹全体の平均容積密度の 平均值を推定できる可能性が示唆された。

\section{2 立木状態のピロディン值と平均容積密度との 関係}

3.2.1 トドマツ精英樹等44クローンの特性

供試したトドマツ精英樹等44クローン135本の樹 高，胸高直径，樹皮の上から測定したピロディン值 (以下，「樹皮付きピロディン值」という。)，樹皮を 剥皮し測定したピロディン值(以下,「ピロディン值」 という。), 平均容積密度, 年輪幅, 樹皮厚の平均值, 最大值, 最小值, 変動係数を Table 4 に示す。また, 各測定形質についてクローンを要因とした分散分析 を行った結果も Table 4 に示す。すべての形質にお いて $1 \%$ 水準で有意なクローン間差が認められた。 $F$ 值は平均容積密度が最も高く, 以下, 樹皮付きピ ロディン值，ピロディン值，樹高，年輪幅，胸高直 径，樹皮厚の順で高かった。平均容積密度は，樹高

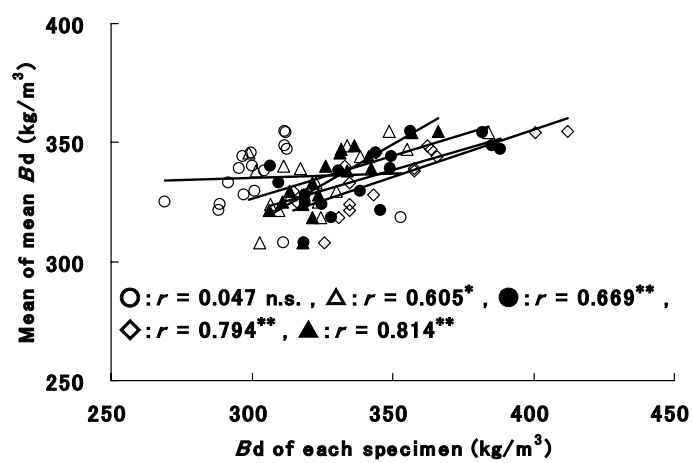

Fig. 6. Relationship between $B d$ of each specimen in the region 1-2 m above ground and mean of mean $B \mathrm{~d}$ in the whole tree.

Legend: $\bigcirc, \triangle, \boldsymbol{O}, \diamond, \boldsymbol{\Lambda}$ : See Fig. $2, B$ d: basic density, ${ }^{* *}$ : significant at $1 \%$ level, ${ }^{*}$ : significant at $5 \%$ level, n.s. : not significant. 
Table 4. Descriptions of sample trees from a clonal archive.

\begin{tabular}{lcrrrrr}
\hline \hline Factor & & \multicolumn{5}{c}{ Avg. } \\
\hline $\mathrm{H}^{(\mathrm{a})}$ & $(\mathrm{m})$ & 13.2 & 18.2 & 7.0 & 17.95 & $4.56^{* *}$ \\
$\mathrm{DBH}^{(\mathrm{b})}$ & $(\mathrm{cm})$ & 18.6 & 31.0 & 8.0 & 25.86 & $2.73^{* *}$ \\
$P_{\mathrm{p}}^{(\mathrm{c})}$ & $(\mathrm{mm})$ & 21.4 & 27.5 & 15.5 & 10.79 & $5.12^{* *}$ \\
$P \mathrm{p}$ with bark & $(\mathrm{mm})$ & 26.3 & 33.9 & 19.3 & 11.02 & $5.42^{* *}$ \\
${\text { Mean } B \mathrm{~d}^{(\mathrm{d})}}$ & $\left(\mathrm{kg} / \mathrm{m}^{3}\right)$ & 334 & 418 & 277 & 7.13 & $8.09^{* *}$ \\
$A \mathrm{rw}^{(\mathrm{e})}$ & $(\mathrm{mm})$ & 2.56 & 4.06 & 1.02 & 22.35 & $2.83^{* *}$ \\
$B \mathrm{t}^{(\mathrm{f})}$ & $(\mathrm{mm})$ & 4.83 & 8.18 & 2.50 & 22.98 & $2.07^{* *}$ \\
\hline
\end{tabular}

Legend: ${ }^{(a)}$ : tree height, ${ }^{(b)}$ : diameter at $1.3 \mathrm{~m}$ above ground, ${ }^{(c)}$ : Pilodyn penetration, ${ }^{(d)}$ : basic density, ${ }^{(\mathrm{e})}$ : annual ring width, ${ }^{(\mathrm{f})}$ : bark thickness, ${ }^{(\mathrm{g})}$ : coefficient of variation, ${ }^{* *}$ : significant at $1 \%$ level.

や胸高直径といった成長形質と比べて，より遺伝的 要因の寄与が高い形質であると考えられる。

3.2.2 ピロデイン值と平均容積密度の関係

樹皮付きピロディン値，ピロディン值と平均容積 密度との関係を Fig. 7 に示す。他の樹種に扔ける報 告 ${ }^{18-23)}$ と同様に，樹皮付きピロデイン值，ピロデ イン值とも $1 \%$ 水準で有意な負の相関関係が認めら れた。ピロデイン值を独立変数 $(x)$, 平均容積密度 を従属変数 $(y)$ とした一次回帰式は, 樹皮付きピロ ディン值で $y=-5.81 x+486.55$, ピロディン值で $y=$ $-8.43 x+514.41$ であった。樹皮付きピロディン值の 方が，ピロデイン值に比べて相関係数が低かった要 因の一つとして，樹皮厚の存在が考えられる。

Table 4 より，平均值に押ける樹皮付きピロディン 值とピロディン值の差と樹皮厚は，ほほ同程度であ った。また，樹皮厚は変動係数が大きく，分散分析 の結果からクローン間差はあるものの, $F$ 值が最も 低かったことから，他の形質に比べ個体間のバラッ

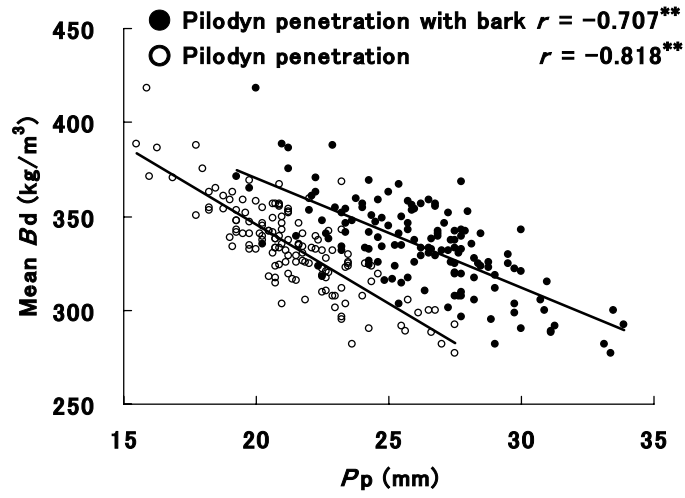

Fig. 7. Relationship between Pilodyn penetration both with and without bark and mean $B \mathrm{~d}$.

Legend: $B \mathrm{~d}$ : basic density, $P \mathrm{p}$ : Pilodyn penetration, ${ }^{* *}$ : significant at $1 \%$ level.
キが大きい形質であると考えられる。また，樹皮付 きでピロディン值を測定する際，樹皮表面の凹凸は ピロディン值に影響を与えると考えられる。しかし， トドマッの樹皮表面は比較的滑らか ${ }^{24)}$ であるので, 樹皮表面の形状が両ピロデイン值の差にあたえる影 響は小さいと考えられる。以上より，トドマツの樹 皮厚の変異が個体間で大きいことの影響が，ピロデ イン值に比べて樹皮付きピロディン值の方が相関係 数の低かった要因の一つとして考えられる。今回の 調查で供試したトドマツ精英樹等クローンで，1ク ローンあたり 3 本以上調查したクローンは27クロー ンあり,それらのクローンの樹皮付きピロディン值, ピロディン值, 平均容積密度の平均值を求め, その 関係を Fig. 8 に示す。個体值と同様に, 樹皮付きピ ロディン值，ピロディン值とも， $1 \%$ 水準で有意な 負の相関関係が認められた。また，相関係数は個体 值より高かった。ピロディン值を独立変数 $(x)$, 平 均容積密度を従属変数 $(y)$ とした一次回帰式は, 樹 皮付きピロディン值で $y=-6.47 x+505.94$, ピロデ

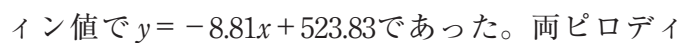
ン值とも，個体值およびクローン平均值において有 意な負の相関関係が認められたが，特に個体值にお いて平均容積密度の值を正確に推定することは難し いと考えられる。

針葉樹を構造材として利用する際, 材のめり込み, 釘の保持力を考慮すれば，容積密度は平均值320 $\mathrm{kg} / \mathrm{m}^{3}$ ，最低 $300 \mathrm{~kg} / \mathrm{m}^{3}$ 以上が好ましいと言われてい $ろ^{25)}$ 。この $300 \mathrm{~kg} / \mathrm{m}^{3}$ 以上を一つの選抜基準值とし た場合，今回供試した材料に打いて，樹皮付きピロ ディン值では $27.5 \mathrm{~mm}$ 以下，ピロディン值では 23.0

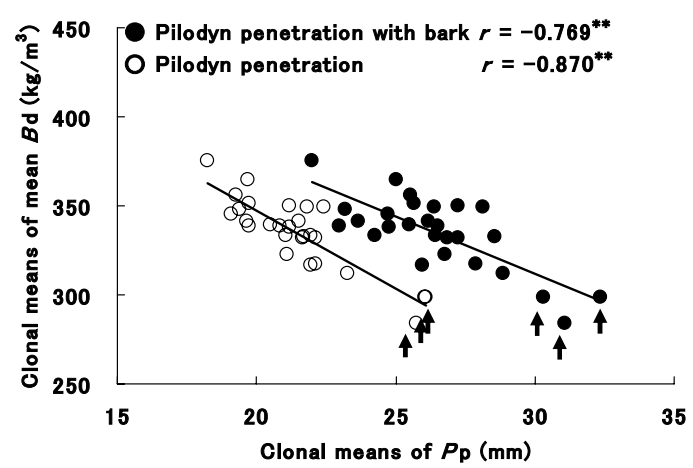

Fig. 8. Relationship between clonal mean value of Pilodyn penetration both with and without bark and that of mean $B \mathrm{~d}$.

Legend: $B \mathrm{~d}$ : basic density, $P \mathrm{p}$ : Pilodyn penetration, ${ }^{* *}$ : significant at $1 \%$ level.

Note : $\quad$ The arrows show the lower mean $B$ d clones. 
$\mathrm{mm}$ 以下を示した全個体で実際に測定した平均容積 密度が $300 \mathrm{~kg} / \mathrm{m}^{3}$ を超えていた。Fig. 7 で示した一次 回帰式にこの值を代入し, 平均容積密度を算出した 結果, 樹皮付きピロディン值で $327 \mathrm{~kg} / \mathrm{m}^{3}$, ピロディ ン值で $321 \mathrm{~kg} / \mathrm{m}^{3}$ となった。このことから，実際に 樹皮付きピロディン值拉よびピロディン值を用いて 選抜を行う際には，選抜基準值を，安全率を見込ん で若干高めに設定する必要があると考えられる。ま た, クローン平均值において $300 \mathrm{~kg} / \mathrm{m}^{3}$ 以下の平均 容積密度を示したクローンは 3 クローンあった。こ れら 3 クローンは, Fig. 8 に矢印で示したクローン であり，樹皮付きピロディン值，ピロディン值とも 高い值を示した。このことから，樹皮ありピロディ ン值抒よびピロディン值を用いて平均容積密度の低 いクローンを特定することができ，それらを除去す ることで採種園の改良や体質改善に役立つと考えら れる。

また， 1 本の測定時間を実際にストップウォッチ で計測したところ，樹皮付きピロディン值は 2 人で 45 秒, ピロディン值は 2 人で 120 秒であった。遺伝 的改良を行うためには，多くの個体の測定を行う必 要があり, 実際の検定においては, より簡便な樹皮 付きピロディン值の方が，有効な指標であると考え られる。

\section{4. 結 論}

トドマツ精英樹等クローンにおける容積密度の樹 高方向変動, ピロディン值と容積密度との関係を調 べ，つぎの結論を得た。

1）トドマツ精英樹等クローンに扔ける平均容積密 度の樹高方向の変動は, クローン毎で異なっており, いくつかのタイプに分類することができた。しかし， 平均容積密度の地上高間の差, 特に胸高部位を含む 地際からの高さ $1 \sim 2 \mathrm{~m}$ 部位と各地上高部位との差 は小さいと考えられた。

2）分散分析の結果から, 平均容積密度はクローン 間, 地上高間で異なり, 各地上高に扔けるクローン 間差拉よびその順位の変動が小さいと考えられた。 また，樹幹全体の平均値と各地上高部位における測 定值の相関係数を求めたところ, ほぼすべての地上 高部位で高い相関係数が認められたが，特に胸高部 位を含む地際からの高さ $1 \sim 3 \mathrm{~m}$ 部位において高か った。以上より, 胸高部付近を含む地際からの高さ 1 3 $\mathrm{m}$ の部位において平均容積密度の遺伝的な違 いを比較できると考えられた。

3）樹皮ありピロディン值，ピロディン值と平均容 積密度との間には, 個体值拉よびクローン平均值と
も，有意な負の相関関係が認められた。樹皮付きピ ロディン值およびピロディン值を用いて選抜を行う

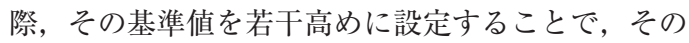
值を上回る平均容積密度の高い個体を選抜すること ができると考えられた。また，クローン平均值を用 いることで平均容積密度の低いクローンを特定する ことができると考えられた。両ピロデイン值を比較 した場合，測定の簡便さから，樹皮付きピロディン 值が平均容積密度の評価に有効な指標であると考え られた。

以上より，2)の結論とあわせ，胸高部位において 樹皮ありピロディン值を測定することにより，トド マツの個体掞よびクローンに扔ける平均容積密度の 評価を立木状態で非破壊的に行うことができると示 唆された。特に, ピロデインを用いた本方法により， 平均容積密度の低いクローンを特定し, 除去するこ とで採種園の改良や体質改善に役立つと考えられ る。

\section{謝 辞}

本研究を行うにあたり, 林木育種協会北海道事務 所と北海道育種場の職員の皆様に，ご協力をいただ いた。また，林木育種センターや北海道育種場の皆 様には, 解析方法などに関してアドバイスを頂いた。 また，本論文の審査者の方々には有益なご意見をい ただいた。ここに厚く打礼を申し上げる。

\section{文献}

1）藤澤義武：林育研報 15,31-107（1998）.

2）宮島 寛：北大演報 37(3), 789-815（1980）。

3）宮島＼cjkstart寛：北大演報 38(2), 305-321（1981）.

4）宮島 寛：北大演報 39(2), 191-212（1982）。

5）片寄 髞, 工藤 弘, 氏家政男：北大演報 49 (2), 201-218 (1992).

6) Katayose, T., Ujiie, M., Kudoh, H. : J. Jpn. For. Soc. 74(5), 426-430 (1992).

7）工藤 弘, 片寄 辣, 氏家政男：北大演報 50 (2), 179-205 (1993).

8) Kadomatsu, M., Kudoh, H., Ujiie, M. : Res. Bull. Hokkaido Univ. For. 51 (1), 14-20 (1994).

9）飯塚和也, 織部雄一朗, 生方正俊 : 木材学会誌 46 (5), 397-405 (2000).

10）飯塚和也, 高倉康造, 生方正俊: 木材学会誌 47 (1), 44-51 (2001).

11）加納 猛：林試研報 134,141-148（1961）.

12）矢幡 久, 宮島 寛, 西林寺隆, 古家宏俊, 巟玉 貴, 汰木達郎, 山本福寿, 久保田茂, 渡部 桂, 野 
上寛五郎, 黒木晴輝：九大演報 57, 149-173 (1987).

13）藤原 健, 山下香菜, 平川泰彦 : 森林総研研報 3(4), 341-348 (2004).

14）田村 明, 高橋 誠, 飯塚和也：日林北支論 53, 9-11 (2005).

15）津島俊治：大分県林業試験場県報 16,1-66 (2006).

16）高橋祐吉：日林中支論 35,85-88（1987）.

17) Hishinuma, Y., Nakata, R., Fukazawa, K. : Res. Bull. Hokkaido Univ. For. 49 (1), 23-35 (1992).

18) Cown, D. J. : N. Z. J. For. Sci. 8 (3), 384-391 (1978).

19) Taylor, F. W. : Forest Sci. 27 (1), 59-61 (1981).
20）中田了五：林木の育種 212,15-16（2004）.

21）武津英太郎, 福田陽子, 高橋 誠, 田村 明, 栗 延 晋：第117回日本森林学会大会学術講演 集, 東京, 2006, L10.

22）石栗 太, 榮澤純二, 齋藤康乃, 飯塚和也, 横田 信三, 吉澤伸夫：木材学会誌 52(6), 383-388 (2006).

23）田村 明, 井城泰一, 坂本庄生, 西岡直樹, 笹島 芳信, 黒沼幸樹 : 北海道の林木育種 45 (2), 13 (2002).

24）林 将之：“樹皮ハンドブック”, 文一総合出 版, 東京, 2006, p. 18.

25）宮島 寛：北大演報 42(4), 1089-1115（1985）。 